Science Life

\title{
CONTRIBUTION OF JĀNIS LIELMANIS IN PLANT BREEDING IN LATVIA
}

\author{
Ina Belicka and Zigurds Kalmanis \\ State Stende Cereal Breeding Institute, "Dižzemes", Dižstende, Lībagu pag., Talsu nov., LV-3258, LATVIA \\ stende.selekcija@apollo.Iv
}

\begin{abstract}
In autumn 1922, the Ministry of Agriculture of Latvia delegated agronomist Jānis Hilarijs Lielmanis (1895-1970) to organise and establish the State Stende Breeding Station. For many years, he was a director (1922-1940) and later a researcher (1945-1956) of the State Stende Breeding Station. Under the guidance of Lielmanis, an infrastructure for breeding work was formed and research into the morphological, biological, and economic traits of local plant varieties obtained from different Latvian regions were begun in the station. Already in 1924, breeders started breeding of cereals, peas, flax, potato, and clover, using selection from local and foreign varieties and also hybridisation. Until 1945, breeders in Stende, under the guidance of Jānis Lielmanis, developed 16 plant varieties, in the period from 1945 to 1960 - 19 varieties. Parallel to his work in Stende, Lielmanis delivered lectures on plant breeding at the University of Latvia (1933-1940) and lectures on genetics, breeding, and seed production at the Latvian University of Agriculture (1940-1944, then Jelgava Academy of Agriculture; 1945-1948). In the later part of his life, Lielmanis worked in the Latvian Scientific Research Institute of Agriculture (1957-1970), where he conducted research in crop farming and breeding of red clover using traditional breeding methods, as well as polyploidy and heterosis methods, which was modern for that time. The research results of oat growth and acclimatisation were summarised by Lielmanis in his habilitation paper (1933), and the results of breeding and growth of red clover - in his dissertation thesis. He was awarded a degree of candidate of agricultural sciences in 1957 and a doctoral degree in 1968. He was very principled in his scientific viewpoints; he supervised five doctoral theses written by candidates of agricultural sciences, published 457 scientific and popular-scientific articles, and wrote six books. Taking into consideration the contribution of Lielmanis to Latvian agricultural science, in 1995, the Jānis Lielmanis award was established, which has been received by breeders, breeding groups, and seed producers for their contribution in plant breeding and seed production in Latvia.
\end{abstract}

Key words: breeder Jānis Lielmanis, State Stende Breeding Station, field crop varieties.

\section{INTRODUCTION}

During the First World War and in the first year of state independency (1918), the agricultural sector of Latvia had strongly suffered. Valuable seed material was lost or mixed during the years of war and destruction; the situation in seed farming was unsatisfactory. Until 1922, Latvia had no bred plant varieties, no research was conducted on suitability of foreign varieties to conditions of Latvian weather and soil. A decree of the Ministry of Agriculture of the Republic of Latvia on the establishment of State Stende Breeding Station was issued in April 1922, and in autumn of the same year the Ministry of Agriculture ordered the new agronomist Jānis Lielmanis to undertake organisation and management of the State Stende Breeding Station, which was located in Stende Manor, Talsi County (Anonymous, 2002). Lielmanis began to study agronomy at the Faculty of Agronomy of Rìga Polytechnical Institute (1915). After the evacuation of the institute to Russia during the First World War, he continued an external course of studies at the Fac- ulty of Agronomy of Moscow Agricultural Institute (19151920). Jānis Lielmanis finished his studies in agronomy at the Faculty of Agriculture of the University of Latvia (1920-1922), receiving, on 12 June 1922, the first-grade degree of an agronomist. In summer he practiced under professor J. Bergs in Vecauce and Denmark. From December 1922 to 1 November 1956, with a few small gaps, Lielmanis, worked in the State Stende Breeding Station. The further work of Lielmanis was connected with the Latvian Scientific Research Institute of Agriculture (1956-1970). This article is a review of the contribution of Jānis Lielmanis in plant breeding, pedagogy, and science popularisation in Latvia.

\section{JĀNIS LIELMANIS - DIRECTOR OF THE STATE STENDE BREEDING STATION}

Undertaking the management of the State Stende Breeding Station, Jānis Lielmanis had to solve many organisational 


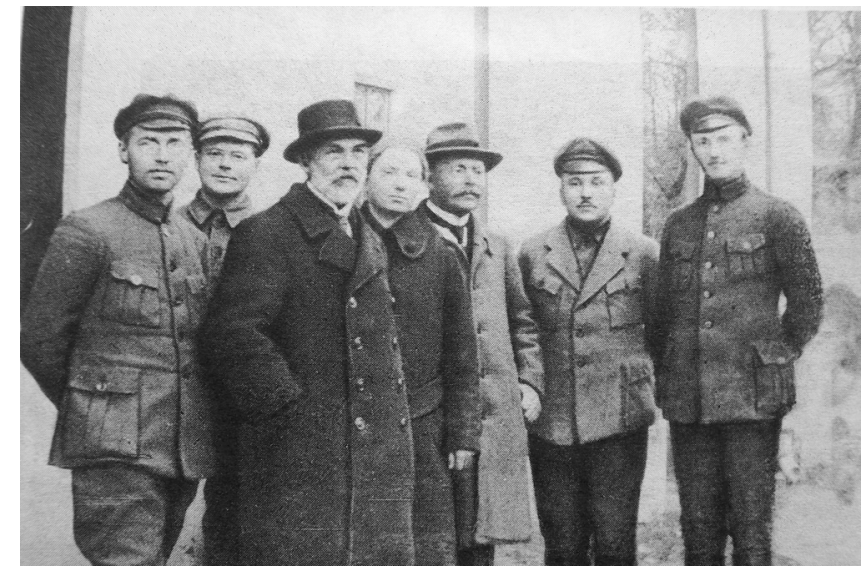

Students of the Faculty of Agriculture, University of Latvia, during practice at Vecauce, the first from left Jānis Lielmanis; the third from the left, Professor Jānis Bergs; the first from right, Emīls Bērziņš (1920-1922).

issues. The main problems in Stende were lack of any experience in field trials and breeding work, few experienced specialists and trained employees, and little equipment for breeding work.

In 1923, agronomist Emīls Bērziņš become Lielmanis’ assistant. With a decree of August 1923, the Agricultural Department of the Ministry of Agriculture sent trainees to Stende. That year also agronomist Jurijs Gabars - later a wheat breeder - started his work in the State Stende Breeding Station. It was an unusual, extraordinary time. Plenty of imagination, energy, determination and good management needed to be devoted to this work. This special time demanded and created strong, willing-to-work and active personnel, as were the new founders of the breeding station.

Lielmanis had good knowledge of several languages Russian, German, English, and French. In 1923 and 1924, Lielmanis and Bērziņš visited Germany, Sweden, and Denmark to become acquainted with methods of breeding and scientific work, work organisation and techniques. In 1926, Lielmanis perfected his knowledge at the Weibulsholm Plant Breeding Institute in Sweden. The new agronomists observed how theoretical issues of breeding and methodology field trials were being solved elsewhere. Publications in Latvian by the agronomists Kārlis Vīgants (Vīgants, 1922) and Jānis Luke (Luke, 1923) on the theory and methodology of plant breeding and G. Mendel's laws of heredity can be considered as a valuable investment in the development of breeding work. The publications provided explanations on modifications and mutations, on mass and individual selection, summarised how practical breeding work should be carried out with self-pollinated and cross-pollinated plants, etc. Knowledge in breeding theory, as well as the gained experience in breeding work organisation, acquaintance with methods of breeding work in foreign countries, together were a great prerogative to the new agronomists, which they used in the State Stende Breeding Station.

For the needs of the Latvian new breeding station, they obtained the required equipment in Germany: single-row and
Jānis Lielmanis — director of the State Stende Breeding Station in 1938.

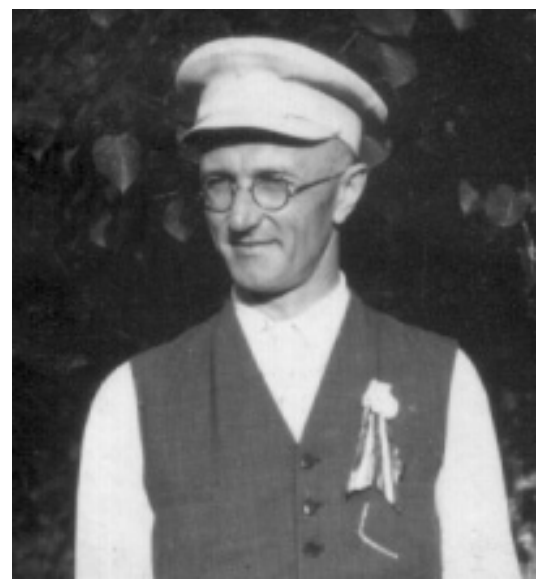

many-row seeders, thresher from the Lanz Company, grain cleaning and sorting machines etc. New facilities in the Station included a modern seed sorting point (1923) and agrochemical laboratory (1923); in the next years also a plant protection department (1925), technological grain laboratory (1927), chemical and processing technology laboratory for flax (1929), the Stende meteorological station (1933), and a scientific library (1938) (Celma u.c., 2002).

Jānis Lielmanis, who managed the State Stende Breeding Station, already in first decade of its existence, established a long-lasting model of management.

When the political situation in Latvia changed, in October 1940, Lielmanis stopped his work in Stende, due to safety reasons, and moved to Rìga, where his work was connected with the Jelgava Academy of Agriculture (1940-1944).

At the end of the Second World War, in autumn 1944, Lielmanis' family returned to Stende. In spring 1945, after a request by Station employees, Lielmanis helped to perform sowing works. The Latvian SSR Ministry of Agriculture, with a decree of 9 May 1945, appointed Jānis Lielmanis as deputy director of the State Stende Breeding Station. However, the Soviet regime did not leave Lielmanis as director of the Station. In January 1946, Lielmanis transferred the management of Stende Station to ex-director of the North Ossetia Breeding Station, Ivan (Jānis) Liepa, who moved to Latvia to fulfill tasks ordered by the USSR People's Commissariat of the Latvian Ministry of Agriculture. Afterwards, Lielmanis became a deputy director of scientific work (Bulbiks un Krotovs, 1994).

Stories of his contemporaries portray Jānis Lielmanis as a director of institution with a peaceful nature, clear and unambiguous logical thought, with an ability to debate without resounding speeches and offence. He was always honest, sincere, truthful, and he supported all the events (Āboliņš, 1994).

\section{JĀNIS LIELMANIS - HEAD OF SCIENTIFIC RE- SEARCH AND BREEDER}

The aim of the Station was to create new, productive cultivated plant varieties, appropriate for local weather and soil conditions, which would be resistant to plant diseases, and 
at the same time also to test the usefulness of foreign varieties under Latvian conditions.

Investigationof local plant varieties. Before the breeding work was started, the main tasks were to analyse the local varieties evaluating their morphological and biological traits as well as their productivity. Stende breeders, under the guidance of Lielmanis, accomplished great work in collecting and evaluating thousands of local seed material samples. Samples of varieties were actively collected throughout Latvia; they were coded and their origin was recorded in journals. The greatest attention was paid to local varieties that had been continuously cultivated in the region for at least a decade. The auditing of plant varieties cultivated in Latvian farms and obtained evaluation results served as the basis for further establishment of breeding strategies.

Young breeders (Jānis Lielmanis, Emīls Bērziņš, Jurijs Garbars), while exploring local variety samples of different crops that were collected from different regions of Latvia, concluded that local varieties had high variability in their biological traits and quality including also their resistance to diseases. As the director of the breeding station, agronomist Jānis Lielmanis himself supervised breeding and field trials of oat, peas, and clover. Evaluating oat samples he distinguished four local oat groups: small, early oat; local unilateral oat; local coarse-grained oat; and local small-grained, medium late oat. Early-ripening and resistance to rust were typical traits for small early oat varieties. Unilateral oat varieties were divided into yellow-grained and white-grained oat. Comparison of trials of pea varieties showed that the populations of local brown-grey angular peas from Kurzeme and Vidzeme had 20-56\% lower yield, when compared to other pea varieties. Clover cultivated in Latvia was classified into early and late clover types. These types differed in their external morphological traits, early-ripening, winter hardiness, productivity, and resistance to clover diseases, and pests. Winter hardiness was evaluated during trials. There were few samples of winter-hardy varieties since not all clover varieties cultivated in Latvia could be considered as local. A large part of the clover samples had originated from foreign varieties, which were imported in Latvia after the First World War (Lielmanis u.c., 1931).

Beginning of breeding work in Stende (1922-1945). It was planned to start breeding work in Stende with rye, barley, flax, oat, potatoes, winter wheat, peas, and clover. The investigation of local varieties identified important traits in breeding. Selection from local varieties and populations, as well from foreign varieties, and hybridisation were the main methods of breeding. Breeding schemes were developed in Stende; taking into the consideration the above-mentioned schemes, the evaluation of selected elite plants and their progenies was carried out. In the period from 1922 to 1940 , under the direction of Jānis Lielmanis and in cooperation with Emīls Bērziņš, Jurijs Garbars, and Nikolajs Konrads, 16 new varieties were developed in Stende.

Agronomist Jānis Lielmanis had an aim for oat breeding creation of oat varieties appropriate for Latvian short growth period, which could combine early-ripening of local small early oat varieties, resistance against rust, and high kernel and protein content in grain. The variety 'Stendes mazās agrās' (1930) was selected from Nereta landraces. It had a 10-14-day shorter growth period than Swalö 'Segerhavre', but had a similar yield, and higher resistance against rust. 'Stendes dzintara' (1932) unilateral oat was bred from Jaunjelgava landrace samples. In breeding of red clover, using the stock selection method and pair cross pollination, the variety 'Stendes vēlais I' (1938) was created (Lielmanis u.c., 1931).

Already at the beginning of station's functioning, in order to increase work efficiency, Lielmanis suggested a wider use of hybridiation in breeding. The theoretical basis of this was formed by G. Mendel's laws of heredity, with which the breeders from Stende were familiar. Hybridisation was initiated in 1924, and an increasing number of crossings were made every year. Breeders crossed local and different foreign varieties, the traits of which they monitored in the next generation of crossing. The main aim, for example in wheat crossing, was to achieve productive varieties with a short vegetation period and to improve grain quality. In crossings among six-row and two-row barley breeders attempts were made to select varieties with grain quality of two-row barley and early-ripening of six-row barley. The most valuable crossings were searched for.

The first progress in the development of new varieties with hybridisation was achieved for oats. From crossing of the oat varieties Swalöf 'Ligovo II' and 'Stendes mazās agrās', breeders created the variety 'Lìgo', which was introduced in production in 1932. From 'Stendes mazās agrās' and the Swalöf cultivated 'Segerhavre' crossing, the 'Pērle' oat variety was created (1942). The winter wheat 'Kursas' (1940), obtained from crossings of local awnless wheat with the variety of Swalöf 'Söl', was characterised with productivity, winter hardiness and average resistance to lodging (Lielmanis u.c., 1931; Holms, 1992).

Observations on distribution of diseases and pests in crop sowings. Observations on diseases of agricultural crops and breeding material in the State Stende Breeding Station were initiated in the first years of its activity. Monitorings were performed by the breeder of each crop species. They described the sensitivity of varieties and selected lines against diseases, and based on this information, chose a resistant initial material (Lielmanis u.c., 1931).

Starting in September 1924, the plant pathology trainee of the Latvian Plant Protection Institute Jānis Skipsna began plant disease research at the Station.

Evaluation of varieties. Beside the breeding work, evaluation of varieties was also performed at the Station. In the first years of the Republic of Latvia, there were no objective data on the yield of foreign varieties and their appropriateness to Latvian weather and soil conditions. Field trials in Stende showed that species of locally cultivated plants exceeded foreign varieties not only in yield, but also with 
other traits. New varieties produced at Stende were evaluated in field trials in experimental farms at Jaungulbene, Priekuli, Vidusmuiža, Valmiera, Vecauce, and in different farms of crop cultivation monitoring societies. This allowed to evaluate their appropriateness for different regions of Latvia. At the same time, breeders in Stende paid great attention to development of agro-technical methods to increase of yield (Lielmanis u.c., 1931).

When evaluating the work achieved in 12 years, Lielmanis pointed out that knowledge of cultivated plant species, methods of their cultivation, requirements for their growth and other traits were already much richer and versatile both for agronomists and all farmers. Farmers had increased interest in cultivated plants and observation skills were improved thanks to articles, lectures and sowing exhibitions provided by Stende Station (Lielmanis, 1935).

Jānis Lielmanis in Stende, 1945-1957. The post-Second World War years introduced changes in the Station's life. A new generation of breeders came to the State Stende Breeding Station. Lielmanis' advice and his work experience in breeding was useful for the new employees.

In 1947-1948, Lielmanis received harsh reprimands on his scientific and pedagogical activity. The Soviet regime considered him as a "bourgeois nationalist". These were unfounded accusations regarding his scientific expertise. Negative publications in the press negatively affected his work in Stende. In December 1947, Lielmanis was lowered in rank, he became the head of breeding and grassland group. The erudite scholar did not comply with the negative views of the Soviet scientist Trofim Lysenko on classical genetics and scientists who were adherents of genetics. Lielmanis remained principled in his scientific conviction. He remained convinced of Mendel's laws and his work and attempted to show their practical significance in breeding. He stayed on the side of classical genetics (Jansons un Vìgants, 1994).

Breeding work in Stende during the post-Second World War years significantly expanded. The breeding material, established in previous years, was carefully evaluated and new initial material was created, using both selection methods and hybridisation. Nineteen varieties submitted to the State Varieties Inspection can be considered as progress of the Stende breeders under the guidance of Jānis Lielmanis. Lielmanis himself was the author of seven of them: red clover 'Stendes vēlais II' and 'Stendes agrais'; oat 'Stendes', 'Mutica 7281'; table peas 'Pionieris', fodder peas 'Stendes Hero' and spring vetch 'Stende 653' (Celma u.c., 2002).

Selection and hybridisation were still used in Stende as breeding methods. With selection, the following varieties were created: rye 'Stendes II' by multifold mass selection, cross pollinated rye from Stende with rye from Petkus and Sangaste; spring wheat 'Stende' by selection from variety 'Aurora'; peas 'Balva' by individual selection from hybrid populations; pea 'Stendes Hero' from Swalöf 'Hero', 'Stendes' field peas by in mass selection from local field peas; red clover 'Stendes vēlais II' by selection from local populations of red clover; red clover 'Stendes agrais' by stock selection from populations obtained from cross pollination among varieties and stocks.

Using hybridization, the following varieties were created: winter wheat 'Kurzeme' ('Jarl'/'Paix'), barley 'Kombainieris' ('Maja'/local from Talsi), oat 'Stendes yellow' ('Stendes dzeltenās') (Stendes 'Dzintara'/ Swalöf 'Segerhavre'// 'Sovetskij'), oat 'Stendes vēlās' (Stendes 'Dzintara'/'Sovetskij'), potatoes 'Stendes baltie' ('Vale'/'Hinderburgas'). The achievements of practical breeding completely renounced the critique of Lysenko on Mendel's theory on heredity (Bulbiks un Krotovs, 1994).

In 1956, Lielmanis produced a review of the long-term work on local red clover varieties and varieties of other regions and their improvement methods, in his dissertation thesis: "Cultivation of late red clover variety 'Stendes vēlais II", which was defended on March 1957 and awarded with a degree of candidate of agricultural sciences (Jansons un Vīgants, 1994).

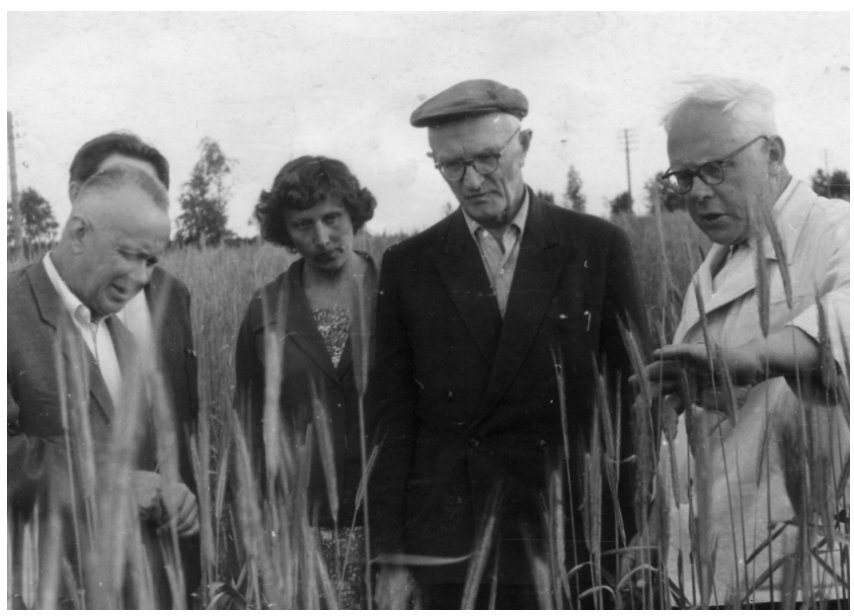

Jānis Lielmanis at the State Stende Breeding Station; from the right, oat breeder Nikolajs Kondrads, Jānis Lielmanis, researcher in the cereal management Aina Stāmere (1954).

Jānis Lielmanis in the field of red clover (in the Scientific Research Institute of Latvian Agriculture at Skrīveri, in 1957).

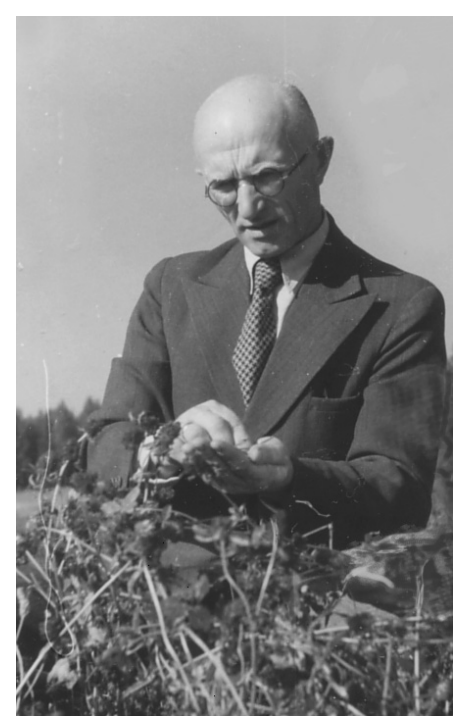


Jānis Lielmanis at the Scientific Research Institute of the Latvian Agriculture, 1956-1970. In 1956, the Academy of Sciences in Riga established the Latvian Scientific Research Institute of Latvian Agriculture (LSRIA); ten breeding and experimental stations and farms were affiliated to the institute. In 1959, the Institute was transferred to Skrīveri. Jānis Lielmanis was appointed from Stende to LSRIA as head of the Crop Farming department. Lielmanis, together with Rūdolfs Eidemanis, continued breeding and cultivation research of red clover, and their colleague Fricis Jansons started work on hybrid clover. The Department of Crop Farming in LSRIA, under the guidance of Lielmanis, conducted research also on other crop species: legumes (Artūrs Antonijs, A. Lācis), introduction of winter rape (Valfrīds Upmanis), mixed cereals and legumes (Otto Sīvin̄š). J. Lielmanis was a scientific supervisor of doctoral theses for all researchers in the department who defended their dissertations, obtaining the degree of candidate of agricultural sciences: Fricis Jansons (1961), Otto Sīviņš (1965), A. Lācis (1968), E. Krēsliṇš (1968), Artūrs Antonijs (1970).

Jānis Lielmanis was a prominent authority among colleagues of the institute. He continuously encouraged everybody to be acquainted with the newest research globally and to improve language fluency. Many research assistants, agronomists, graduate students who needed help and support concerning different issues, turned to Lielmanis for advice and consultation. They knew that Lielmanis would never refuse to help, would give the necessary advice, and try to answer every question (Antonijs, 1994). He taught his colleagues scientific accuracy, honesty, adherence to principles, love for work, enterprise, and complete self-devotion to the chosen aim in science for our nation (Špogis, 1994).

Latvia highly appreciated the investment of Jānis Lielmanis in agricultural science, especially in breeding. In 1957, the LSSR Supreme Council awarded him the honorary title of meritorious agronomist, and in 1959, the LSSR Council of Ministers awarded him the Latvian SSR State Prize for achievements in clover breeding and improvement of seed production methods (Jansons un Vīgants, 1994). In 1965, Lielmanis was awarded the LSSR honorary title of meritorious scientist (Jansons un Vīgants, 1994). Lielmanis showed his adherence to principles also in the 1960s, when the system of agricultural grassland was subject to criticism. He did not agree with the decision on interruption of scientific research on clover.

Jānis Lielmanis reviewed research on red clover in his doctoral dissertation, ,Red clover and its cultivation in experimental interpretation", which was defended in May 1968 for a doctor degree of agricultural sciences.

In the LSRIA, Lielmanis continued his studies on the use of heterosis to increase clover variety yield, which he had initiated already in Stende. The red clover variety 'Skrīveru agrais' can be mentioned as a result of studies on heterosis (authors Jānis Lielmanis, Fricis Jansons, A. Ciska. E. Mačulsska). Lielmanis was acquainted with world literature and the newest breeding methods. He came to conclusion that, along with traditional methods based on classical genetics, breeders must use also newer methods. He was interested in tetraploidy clover varieties, which were created by duplicating the number of clover chromosomes. In 1969, he set up trials to create tetraploidy forms of local red clover. Jānis Lielmanis died on 4 March 1970, but the work he had started was continued and in 1982 the first variety of tetraploidy red clover 'Dīvaja' was developed (authors F. Jansons, A. Ciska) (Berzins, 1994).

\section{JĀNIS LIELMANIS — A PEDAGOGUE}

Alongside his work in Stende, on 28 April 1933, Lielmanis presented his habilitation thesis "Studies on cultivation and acclimatization of oat varieties" in the Department of Crop Farming in the Faculty of Agriculture in University of Latvia, which allowed him to become a private associate professor in the Faculty of Agriculture from 1933 to 1940. In this university he presented a course on plant breeding. In 1940, the Faculty of Agriculture of the University of Latvia was reformed as the Latvian Academy of Agriculture. After establishing the Soviet regime, Lielmanis could no longer continue as the director of the State Stende Breeding Station, and therefore, in 1940 he moved to Rìga. From 1940 to 1944, Lielmanis worked as an associate professor in the Jelgava Agricultural Academy, where he read a course of lectures on plant breeding and genetics. During this time period, he continued his studies on clover and cereal crops in Vecauce research farm.

In 1945, Lielmanis again began work in the Faculty of Agriculture, Latvian University of Agriculture, heading the Department of Breeding and Genetics. He was a talented lecturer. Students were attracted and inspired by his individuality and spiritual energy. He shared his knowledge and experience in a provincing, free manner (Zālītis, 1994). During the time of Joseph Stalin's personality cult (19471948), Lielmanis was criticised and condemned for "pseudo-scientific" articles in the book Augkopiba [Crop farming]. He was expelled from the Latvian Academy of Agriculture (Jansons un Vīgants, 1994; Dālmane, 2010). Lielmanis could not endure the crude and even vulgar interpretation of genetics and breeding — the branches he represented.

\section{JĀNIS LIELMANIS - A POPULARIZER OF SCIEN- TIFIC ACHIEVEMENTS}

Journals and newspapers on agriculture regularly published Lielmanis' articles on cultivation of crops, results of research, breeding and other issues, which were of interest to farmers. Starting with his first article (a pen-name J. Kurs was used from 1933 to 1940) in 1922 in the magazine Lauksaimnieks [Farmer], he regularly provided advice to farmers in national and regional newspapers and magazines. 
His verity: "Reading lectures and writing articles are a noble field of activity in nation's tillage" should be taken into consideration by every scientist and researcher.

The total number of scientific and popular science publications by Jānis Lielmanis is 457 (see the list of his most relevant publications at the end of this article).

\section{JĀNIS LIELMANIS AWARD}

J. Lielmanis taught: "The ideas and work of scientists serve for progress of humanity and stay in its golden fund. Therefore, honest work of a scientist is a noble mission, worthy to sacrifice one's creative life for."

The Latvian Academy of Agriculture and Forestry Science, Scientific Research Institute of Agriculture of the Latvia University of Agriculture (at that time, the Research Institute of Agriculture Skriveri) and the State Stende Cereal Breeding Institute (at that time Stende Breeding and Experimental Station) established the award of Dr. agr. Jānis Lielmanis (1895-1970) on the $100^{\text {th }}$ anniversary of the longterm director, erudite breeder and agronomist. The competition for the Jānis Lielmanis prize is announced once in three years; the aim is to honour Latvian researchers or groups, specialised farms, seed farming companies and specialists of crop breeding and seed farming on achievements in plant crop breeding, seed farming, and popularisation of such work. Candidates for the competition are nominated by scientific agricultural and educational institutions, as well as by public organisations related to agriculture.

Winners of the award (prize):

- 1995 - Professor of the Department of Crop Farming of the Latvian University of Agriculture, Dr. biol. Ina Belicka.

- 1998 - Deputy Director in scientific work of the Study and Research Farm "Vecauce", Dr. agr. Zinta Gaile.

- 2001 - Pea breeder in Priekuḷi Plant Breeding Station, Dr. agr. Maija Vitjazkova, and researcher at the Research Institute of Agriculture Skrīveri, Dr. agr. Pēteris Bērziņš.

- 2004 - Virologist and long-term standing director of Priekuḷi Breeding Station, Dr. agr. Uldis Miglavs, and an oat breeder in State Stende Breeding Station, Māra Gruntina.

- 2007 - Agronomist in “Uzvara-Lauks” Ltd (Bauska District), Vizma Valterāne.

- 2010 - Potato breeding group of State Priekul,i Plant Breeding Institute: Dr. agr. Ilze Skrabule, Dr. agr. Gunta Bebre, Marija Oša, Brigita Ozolina, Lolita Devene, and Aija Legzdina; red clover breeder at the Scientific Research Institute of Agriculture, Latvian University of Agriculture, Dr. agr. Biruta Jansone, and wheat breeder in State Stende Cereal Breeding Institute $M g$. agr. Vija Strazdina.

\section{CONCLUSION}

The State Stende Breeding Station was the first breeding station established with the support of the Latvian government and has preserved this status until today. The achievements and progress of the State Stende Breeding Station are mostly a merit of its first director, erudite researcher and agronomist Jānis Hilarijs Lielmanis. The foundation of the work in the State Stende Breeding Station, selfless work of first breeders in research of local varieties and establishment of new varieties make the basis for successful work already for 90 years. Jānis Lielmanis was an excellent director, researcher, breeder, educator and publicist, he created a good school for his contemporaries, which serve to lead also young researchers today.

\section{THE MOST RELEVANT PUBLICATIONS BY JĀNIS LIELMANIS}

\section{Books}

Lielmanis, J., Bērzin̄š, E. (1924). Kā dzīvo un strādā lauksaimnieki ārzemēs. 5. burtn.: Par Vācijas, Dānijas un Zviedrijas sēklkopju un selekcijas staciju iekārtu un darbību [How Farmers Live and Work Abroad. Book 4: On facilities and activities of German, Danish and Swedish seed farmers and breeding stadions]. Rīga: Lauksaimniecības departaments. 65 lpp. (in Latvian).

Lielmanis, J., Bērzin̄š, E., Garbars, J. (1931). Selekcijas un izmēéginājumu darbi Valsts Stendes selekcijas stacijā, 1923.-1938. [Breeding and Experimental Works in the State Stende Breeding Station, 1923-1938]. Rìga: Valters un Rapa. 289 1pp. (in Latvian).

Lielmanis, J. (1938). Augkopība [Crop Farming]. Rīga: Lauksaimniecības pārvalde. 307 lpp. (in Latvian).

Lielmanis, J. (1944). Augkopība. 2. izd. [Crop Farming. $2^{\text {nd }}$ edn.]. Rīga: A. Punkas apgāds. 295 lpp. (in Latvian).

Lielmanis, J. (1945). Augkopība. 3. izd. [Crop Farming. $3^{\text {rd }}$ edn.]. Rīga: VAPP grāmatu apgāds. 288 lpp. (in Latvian).

Lielmanis, J. (1948). Sarkanā ābolina sēklaudzēšanas agrotehnika [Agrotechnics of Seed Production of Red Clover]. Rīga: Latvijas Valsts izdevniecība. 20 lpp. (in Latvian).

Lielmanis, J. (1958). Sarkanā ābolina vietējās škirnes un to uzlabošana [Local Varieties of Red Clover and Their Improvement]. Rīga: Latvijas Valsts izdevniecība. 60 lpp. (in Latvian).

Lielmanis, J., Godmanis, T. (1970). Sarkanā ābolina audzēšana [Red Clover Cultivation]. Rīga: Liesma. 195 lpp. (in Latvian).

\section{Articles}

Lielmanis, J. (1931). Aklimatizācijas izmēg̣inājumi ar ārzemju auzu šḳirnēm [Acclimatisation trials with foreign oat varieties]. Lauksaimniecības mēnešraksts, Nr. 3, 185-198.

Lielmanis, J. (1935). Optimālais auzu sējas laiks dažādos Latvijas apgabalos [The optimum time for sowing oats in different Latvian regions]. Lauksaimniecības mēnešraksts, Nr. 3, 133-169.

Lielmanis, J. (1936). Izmēǵinājumi ar ārzemju un vietējām auzu škirnēm laikā no 1928. līdz 1935. gadam [Trials with foreign and local oat varieties from 1928 to 1935]. Lauksaimniecības mēnešraksts, Nr. 7/8, 371-393.

Lielmanis, J. (1936). Izmēǵinājumi un selekcijas darbi ar sarkano ābolinu [Trials and breeding work with red clover]. Lauksaimniecības mēnešraksts, Nr. 4, 195-259.

Lielmanis, J. (1936). Pētījumi par Latvijas sarkanā āboliṇa tipa tīrību [Studies on purity of Latvian red clover]. Grām.: X agronomu biedrības kongresa materiāli (29.-38. 1pp.). Rīga: Latvijas Agronomu biedrība. 
Lielmanis, J. (1962). Škirne kā faktors ziemāju labību un āboliṇa ziemcietības kāpināšanai [Variety as a factor in increasing winter hardiness of winter cereals and clover]. Grām.: Augu ziemcietība, aukstumizturība un to kāpināšanas iespējas (56.-68. 1pp.). Rīga: Latvijas Valsts izdevniecība.

Lielmanis, J. (1966). Pētījumi par sarkanā āboliṇa heterozi [Studies on heterosis of red clover]. Grām.: Augsne un raža: zinātnisku rakstu krājums. 14. laid. (171.-182. lpp.). Latvijas Zemkopỉbas ZPI.

\section{REFERENCES}

Celma, I., Kaḷiņina, S., Kalmanis, Z., Krotovs, M., Strazdina, V., Zute, S. (red.). (2002). Valsts Stendes selekcija laiku lokos. No 1922. gada 23. aprīla lìdz mūsdienām [State Stende Breeding in the course of time. From 23 April 1922 until nowadays]. Valsts Stendes selekcijas stacija. 123 lpp. (in Latvian).

Āboliņ̧̌, J. (1994). Saskarsme ar Jāni Lielmani [Communication with Jānis Lielmanis]. Grām.: Jānis Lielmanis dzìve un darbā [Jānis Lielmanis in his life and work] (52.-74. lpp.). Latvijas Valsts zemkopības zinātniskās pētniecības institūts ,Agra” (in Latvian).

Antonijs, A. (1994). Zinātnei un tautai veltīts mūžs [Life dedicated to science and people]. Grām.: Jānis Lielmanis dzìvē un darbā [Jānis Lielmanis in his life and work] (103.-108. lpp.). Latvijas Valsts zemkopības zinātniskās pētniecības institūts „Agra” (in Latvian).

Bērziņš, P. (1994). Sarkanā āboliņa selekcija [Breeding of red clover]. Grām.: Jānis Lielmanis dż̄̄ve un darbā [Jānis Lielmanis in his life and work] (33.-46. lpp.). Latvijas Valsts zemkopības zinātniskās pētniecības institūts ,Agra” (in Latvian).

Dālmane, A. (2010). Stalịna represijas gadi Latvijas Universitātē [Years of Stalin's repression at the University of Latvia]. Grām.: Acta Medico-historica Rigensia (298.-311. 1pp.). Rīga: Paula Stradiṇa Medicīnas vēstures muzejs (in Latvian).
Bulbiks, P., Krotovs, M. (1994). Stendes selekcijas un izmēǵinājumu stacija izaugsme. [Growth of the Stende Breeding and Experimental Station]. Grām.: Jānis Lielmanis dż̄ivē un darbā [Jānis Lielmanis in his life and work (52.-74. lpp.). Latvijas Valsts zemkopības zinātniskās pētniecības institūts „Agra” (in Latvian).

Jansons, F., Vīgants, G. (1994). Jāṇa Lielmaņa dzīves ceḷš [Way of Life of Jānis Lielmanis]. Gram.: Jānis Lielmanis dzīvēe un darbā [Jānis Lielmanis in his life and work] (7.-32. lpp.). Latvijas Valsts zemkopības zinātniskās pētniecības institūts „Agra” (in Latvian).

Holms, I. (red.) (1992). Laukaugu selekcija Latvijā [Field Crop Breeding in Latvia]. Rīga: Avots. 192 lpp. (in Latvian).

Lielmanis, J., Bērziņš, E. Garbars, J. (1931). Selekcijas un izmēǵinājumu darbi Valsts Stendes selekcijas stacijā [Breeding and experimental works at the State Stende plant breeding station]. Rìga: Valters un Rapa. 289 lpp. (in Latvian).

Lielmanis, J. (1935). Stendes selekcijas stacijas sasniegumi [Achievements of the State Stende Breeding Station]. Zemkopis, Nr. 19, 424-425 (in Latvian).

Luke, J. (1923). Selekcija. Škirnuu izaudzēššna un izkopšana [Breeding. Creating and improvement of varieties]. Rīga: Lauksaimniecības departaments. 36 lpp. (in Latvian).

Špogis, K. (2004). Jānis Lielmanis — speciālists ar daudzpusīgām interesēm [Jānis Lielmanis — a specialist with diversified interests.] Grām.: Jānis Lielmanis dzìvē un darbā [Jānis Lielmanis in his life and work (85.-88. lpp.). Latvijas Valsts zemkopības zinātniskās pētniecības institūts „Agra” (in Latvian).

Vīgants, K. (1922). Lauksaimniecības augu izlases teorija un metodika [Agricultural plant breeding theory and methods]. Cēsis un Valmiera: K. Dūnis. 60 lpp. (in Latvian).

Zālītis, J. (1994). Problēmu spriegums [Tension of problems]. Grām.: Jānis Lielmanis dzīvē un darbā [Jānis Lielmanis in his life and work (83.-85. lpp.). Latvijas Valsts zemkopības zinātniskās pētniecības institūts „Agra” (in Latvian).

\section{JĀNA LIELMANA IEGULDĪJUMS AUGU SELEKCIJĀ LATVIJĀ}

Jānis Lielmanis (1895-1970) bija Stendes selekcijas stacijas dibinātājs un ilggadīgais direktors (1922-1940), vēlāk zinātniskais līdzstrādnieks (1945-1956). Dzīves otrā pusē J. Lielmanis strādāja Latvijas Lauksaimniecības institūtā (1957-1970). Vinš ir daudzu lauksaimniecības augu šķirņu autors. Lielu uzmanību J. Lielmanis veltījis pedagoǵiskajam darbam — lasījis lekcijas Latvijas Lauksaimniecības akadēmijā, sarakstījis mācību grāmatu augkopībā, vadījis vairāku disertāciju izstrādi. Daudzu zinātnisku un populārzinātnisko rakstu autors. 